\title{
Increased dosage of a transcriptional activator gene enhances iron-limited growth of Saccharomyces cerevisiae
}

\author{
DAVID EIDE* and LEONARD GUARENTE \\ Department of Biology, Massachusetts Institute of Technology, Cambridge, MA 02139, USA
}

(Received 29 August 1991; accepted 23 October 1991)

\begin{abstract}
We have selected for genes that, when present in multiple copies, enhance growth of wild-type cells of Saccharomyces cerevisiae in an iron-limiting medium. A gene designated FUP1, for 'ferric utilization proficient', was isolated by this approach. Increased dosage of FUP1 reduces the concentration of iron in the medium required for efficient growth and confers elevated levels of iron uptake activity in iron-limited cells. Disruption of the FUP1 locus reduces wild-type iron uptake rates by 2 -fold in cells grown on raffinose medium but has no effect on glucosegrown cells. DNA sequencing showed that FUP1 encodes a hydrophilic $43 \mathrm{kDa}$ protein identical to $M S N 1$, a gene encoding a transcriptional activator implicated in carbon source regulation. Our results suggest that FUP1/MSN1 also regulates synthesis of gene products involved in iron uptake.
\end{abstract}

\section{Introduction}

Iron is a critically important component of cellular biochemistry. Its two stable oxidation states, $\mathrm{Fe}^{3+}$ and $\mathrm{Fe}^{2+}$, allow the metal to participate in a wide variety of redox reactions involved in such diverse processes as the synthesis of DNA, lipids and amino acids, and in respiratory electron transport. Although abundant, iron is often unavailable for cell growth because the oxidized form, $\mathrm{Fe}^{3+}$, is extremely insoluble at neutral $\mathrm{pH}$. Therefore, organisms have evolved mechanisms to efficiently obtain iron from their environment (for a comprehensive review, see Winkelmann et al., 1987). For example, many bacteria and fungi secrete ironbinding compounds known as siderophores that bind extracellular iron; this complex is then brought into the cell via a receptor-mediated process.

The iron transport systems of many organisms are regulated in response to iron limitation and metabolic demand for iron (Winkelmann et al., 1987). In bacteria and fungi, the synthesis, secretion and internalization of siderophores are increased during growth in low iron environments.

* Author for correspondence. Present address: Department of Biochemistry and Molecular Biology, University of Minnesota-Duluth, Duluth, MN 55812-2487, USA. Tel. 218-726-6508; fax 218-726-6235; email deide@ub.d.umn.edu.

Abbreviations: DDW, deionized-distilled water; LIM, low-iron medium; SD medium, synthetic defined medium; YPD, yeast extract/ peptone/glucose; cAPK, cAMP-dependent protein kinase.
The yeast Saccharomyces cerevisiae apparently does not produce any siderophores (Schwyn \& Neilands, 1987). The major mechanism of iron accumulation by $S$. cerevisiae involves an iron reductase, located in the plasma membrane, that reduces $\mathrm{Fe}^{3+}$ to $\mathrm{Fe}^{2+}$ (Lesuisse $e t$ al., 1987; Lesuisse \& Labbe, 1989; Dancis et al., 1990). Studies indicate that the reductase is probably encoded by the $F R E 1$ gene (Dancis et al., 1990). Reduced iron is then transported into the cell by a carrier or channel located in the plasma membrane. The activity of the membrane iron reductase is regulated in response to iron availability, i.e. the reductase is more active as iron becomes increasingly limited (Dancis et al., 1990). This regulation is probably the result of transcriptional control because steady-state levels of FREI mRNA correspond to the level of reductase activity (Dancis et al., 1990).

The long-range goal of our research is to understand the process of iron uptake in yeast and determine how cells adapt to iron limitation. This communication describes a genetic strategy that we have used to identify genes involved in iron metabolism. We have screened a multicopy plasmid library for genes that, when present in several copies per cell, enhance growth of wild type cells in iron-limiting conditions. Using this approach we have identified the $F U P I$ gene. DNA sequencing revealed that $F U P I$ is identical to $M S N 1$, a transcriptional activator involved in carbon source regulation (Estruch \& Carlson, 1990). Increased gene dosage of FUPI/MSNI reduces the amount of iron required for optimum cell 
growth. This lower iron requirement is because FUPI/MSNI stimulates iron uptake during growth in low iron medium.

\section{Methods}

Preparation of low-iron medium ( $L I M)$. LIM is based on the Wickerham nitrogen base recipe (Wickerham, 1946) with two modifications essential to control iron availability. First, 1 mM-EDTA is added to provide a buffering capacity for the concentrations of multivalent metal cations. Second, the medium is $\mathrm{pH}$-buffered at $\mathbf{4 . 2}$ with $20 \mathrm{~mm}$-citrate to prevent $\mathrm{pH}$ changes that could greatly alter the metal binding ability of EDTA. This is an important modification because growing yeast can acidify an unbuffered medium to below pH 3.

The stock solutions from which LIM was made are described in Table 1. These were prepared from reagent grade chemicals and deionized-distilled water (DDW). The $\mathrm{pH}$ values of stocks 1 and 7 were adjusted to 8.0 and 4.2 , respectively, with $\mathrm{HCl}$. Stock 10 and the $\mathrm{FeCl}_{3}$ stocks were prepared in $0 \cdot 1 \mathrm{M}-\mathrm{HCl}$. Solutions were filter-sterilized with $0.45 \mu \mathrm{m}$ cellulose nitrate filters (Costar) and stored in polycarbonate bottles. To prepare the medium, the stock solutions were added in numerical order to $438.5 \mathrm{ml}$ of DDW, filter-sterilized, and stored in polycarbonate bottles. Iron supplements were added after sterilization, and the medium was allowed to equilibrate for at least $16 \mathrm{~h}$ before use.

Several precautions were taken to avoid contaminating the medium with iron. Culture flasks and graduated cylinders used in preparing the stocks and the medium were acid-washed in $0.1 \mathrm{M}-\mathrm{HCl}$. Disposable plastic pipettes were used for adding stock solutions. Atomic absorption spectroscopy showed that the basal concentration of iron in LIM was $50 \mathrm{nM}$. Contamination from culture inocula was minimized by inoculating from cultures that had negligible iron concentrations when diluted into fresh medium (see below). Finally, because concentrations of free iron can be increased by the photoreduction of ferric to ferrous iron in the presence of EDTA, the media were prepared and inoculated in indirect light, all solutions containing EDTA were stored in the dark, and cultures were incubated in the dark.

Strains and genetic methods. All strains used in this work are congenic and related to the S288C strain of Saccharomyces cerevisiae. Strains used were: DBY2063 (MATa leu2-3,112 ura3-52), DEY1194 (MATa leu2-3,112 ura3-52 fup1-1::URA3), DEY1296 (MATa leu2-3,112 ura3-52 his4-619) and DEY1298 (MATa leu2-3,112 ura3-52 his4-619 fup 1-1::URA3). Standard methods were used for genetic analysis and transformation (Sherman et al., 1986). Yeast cells were grown in yeast extract/peptone/glucose (YPD) or synthetic defined (SD) medium containing either $2 \%(\mathrm{w} / \mathrm{v})$ glucose or $2 \%(\mathrm{w} / \mathrm{v})$ raffinose as the carbon source (Sherman et al., 1986).

Iron-limited cultures were prepared in LIM supplemented with 0 to $25 \mu \mathrm{M}-\mathrm{FeCl}_{3}$. The various LIM media used in this work are referred to as ' $\operatorname{LIM}(x)$ ' where $x=$ the concentration, in $\mu \mathrm{M}$, of added $\mathrm{FeCl}_{3}$. Cells were grown with aeration at $30^{\circ} \mathrm{C}$ in polypropylene culture tubes or in acid-washed polycarbonate Erlenmeyer flasks. Inocula for low iron cultures were prepared by growing the cells to saturation in YPD, diluting $1: 1000$ into LIM(10), and growing to saturation. Fresh media were inoculated 1:1000 with this culture. Cell growth was monitored periodically by measuring the optical density at $600 \mathrm{~nm}\left(\mathrm{OD}_{600}\right)$ and these values were converted into cell number with a standard curve. Specific growth rates $(=\ln 2 /$ doubling time $)$ during exponential growth were calculated from linear regressions of a plot of $\ln$ (cell number) vs time.

Isolation of multicopy enhancers of iron-limited growth. DBY2063 was transformed with a plasmid library constructed from partially digested
Table 1. Composition of LIM

\begin{tabular}{|c|c|c|c|c|}
\hline Stock & $\begin{array}{l}\text { Fold } \\
\text { concn }\end{array}$ & Component & $\begin{array}{l}\text { Stock } \\
\text { concn } \\
\text { (M) }\end{array}$ & $\begin{array}{c}\text { Final } \\
\text { concn } \\
\text { (M) }\end{array}$ \\
\hline 1 & 500 & $\mathrm{Na}_{2}$ EDTA $2 \mathrm{H}_{2} \mathrm{O}$ & $5 \cdot 0 \times 10^{-1}$ & $1.0 \times 10^{-3}$ \\
\hline 2 & 100 & $\begin{array}{l}\mathrm{MgSO}_{4} \cdot 7 \mathrm{H}_{2} \mathrm{O} \\
\mathrm{NaCl}\end{array}$ & $\begin{array}{l}5.0 \times 10^{-1} \\
1.0 \times 10^{-1}\end{array}$ & $\begin{array}{l}5.0 \times 10^{-3} \\
1.0 \times 10^{-3}\end{array}$ \\
\hline 3 & 100 & $\mathrm{CaCl}_{2} \cdot 2 \mathrm{H}_{2} \mathrm{O}$ & $1.0 \times 10^{-1}$ & $1.0 \times 10^{-3}$ \\
\hline 4 & 100 & $\begin{array}{l}\text { Uridine } \\
\text { L-Histidine } \\
\text { L-Leucine } \\
\text { L-Lysine }\end{array}$ & $\begin{array}{l}4.0 \times 10^{-2} \\
5.0 \times 10^{-2} \\
7.6 \times 10^{-2} \\
7.0 \times 10^{-2}\end{array}$ & $\begin{array}{l}4.0 \times 10^{-4} \\
5.0 \times 10^{-4} \\
7.6 \times 10^{-4} \\
7.0 \times 10^{-4}\end{array}$ \\
\hline 5 & 100 & $\left(\mathrm{NH}_{4}\right)_{2} \mathrm{SO}_{4}$ & $3 \cdot 8$ & $3.8 \times 10^{-2}$ \\
\hline 6 & 100 & $\mathrm{KH}_{2} \mathrm{PO}_{4}$ & $1.0 \times 10^{-1}$ & $1.0 \times 10^{-3}$ \\
\hline 7 & 50 & $\mathrm{Na}_{3}$ Citrate $2 \mathrm{H}_{2} \mathrm{O}$ & $1 \cdot 0$ & $2.0 \times 10^{-2}$ \\
\hline 8 & 20 & Glucose & $2 \cdot 2 \times 10^{-1}$ & $1.1 \times 10^{-2}$ \\
\hline 9 & 1000 & $\begin{array}{l}\text { d-Biotin } \\
\text { Ca Pantothenate } \\
\text { myo-Inositol } \\
\text { Pyridoxin } \\
\text { Thiamin. } \mathrm{HCl}\end{array}$ & $\begin{array}{l}1.6 \times 10^{-5} \\
1.7 \times 10^{-3} \\
1.0 \times 10^{-2} \\
2.0 \times 10^{-3} \\
1.0 \times 10^{-3}\end{array}$ & $\begin{array}{l}1.6 \times 10^{-8} \\
1.7 \times 10^{-6} \\
1.0 \times 10^{-5} \\
2.0 \times 10^{-6} \\
1.0 \times 10^{-6}\end{array}$ \\
\hline 10 & 10000 & $\begin{array}{l}\mathrm{H}_{3} \mathrm{BO}_{3} \\
\mathrm{Cu}_{2} \mathrm{SO}_{4} \cdot 5 \mathrm{H}_{2} \mathrm{O} \\
\mathrm{KI} \\
\mathrm{MnCl}_{2} \cdot 4 \mathrm{H}_{2} \mathrm{O} \\
\mathrm{Na}_{2} \mathrm{MoO}_{4} \cdot 2 \mathrm{H}_{2} \mathrm{O} \\
\mathrm{ZnSO}_{4} \cdot 7 \mathrm{H}_{2} \mathrm{O}\end{array}$ & $\begin{array}{l}1.0 \times 10^{-1} \\
2.0 \times 10^{-3} \\
5 \cdot 0 \times 10^{-3} \\
2.5 \times 10^{-1} \\
1.0 \times 10^{-2} \\
3 \cdot 3 \times 10^{-1}\end{array}$ & $\begin{array}{l}1.0 \times 10^{-5} \\
2.0 \times 10^{-7} \\
5.0 \times 10^{-7} \\
2.5 \times 10^{-5} \\
1.0 \times 10^{-6} \\
3.3 \times 10^{-5}\end{array}$ \\
\hline
\end{tabular}

Sau3A genomic fragments cloned into the BamHI site of YEp24 (Carlson \& Botstein, 1982). Approximately 15000 independent transformants were isolated and pooled into three populations of approximately 5000 transformants each. These pools were inoculated 1:1000 (approximately $10^{6}$ cells per pool) into $\operatorname{LIM}(0 \cdot 25)$, grown to saturation, and inoculated $1: 1000$ into fresh $\operatorname{LIM}(0 \cdot 25)$. This process was repeated three times after which two of the three pools exhibited markedly faster growth rates in $\operatorname{LIM}(0 \cdot 25)$ than did DBY2063 transformed with only the YEp24 vector. Several individual plasmidbearing cells were cloned from these two pools and tested for improved growth in $\operatorname{LIM}(0 \cdot 25)$.

DNA manipulations. Standard methods were used to manipulate and analyse DNA (Sambrook et al., 1989). The plasmids pDE103, pDE104, $\mathrm{pDE} 105$ and $\mathrm{pDE} 106$ are deletion derivatives of $\mathrm{pDE} 1$. We constructed these plasmids by utilizing convenient restriction sites within the pDE1 insert and parent vector YEp24 (see Fig. 3). Non-compatible overhanging termini were filled in by treatment with DNAase I Klenow fragment prior to ligation (Sambrook et al., 1989). pDE103 was constructed by digestion of $\mathrm{pDE} 1$ with $S m a \mathrm{I}$ and partial digestion with $E c o$ RV. The appropriate fragment was isolated by gel electrophoresis and electroelution onto DEAE paper (Greene \& Guarente, 1987) and re-ligated. pDE104 was constructed in a similar manner by digesting with Sal I and partial digestion with $S n a B I$. We constructed pDE 105 by digesting pDE1 with SalI and MluI. pDE106 was constructed by digestion of pDEl with SmaI and MluI. A deletion allele of FUPI, designated fup $1-1:: U R A 3$, was constructed by first inserting the $6 \mathrm{~kb}$ pDE1 SalI-SmaI fragment into pSP65 to generate pDE81. Then pDE81 was digested with $X h o \mathrm{I}$ and $S n a \mathrm{BI}$ and the $1 \cdot 1 \mathrm{~kb}$ ClaI-SmaI URA3 fragment from YEp24 was inserted, following Klenow treatment of the overhanging termini, to generate pDE82. We constructed pDE 107 by inserting the $5.5 \mathrm{~kb}$ Sal I-Smal fragment from pDE82 into YEp351 (Hill et al., 1986). All pDEl derivative plasmids 
were tested for a growth enhancement effect by transforming the plasmids into DBY2063 and measuring cell growth rate in $\operatorname{LIM}(0 \cdot 25)$. The $2.3 \mathrm{~kb} X b a \mathrm{I}-E c o$ RI fragment from pDE82 was used to replace the wild-type gene in DBY2063 by gene transplacement (Rothstein, 1991) to generate the strain DEY1194. Transplacement was confirmed by Southern blot analysis.

To sequence the FUPI gene, we inserted the $6 \mathrm{~kb} S a l \mathrm{I}-S m a \mathrm{I}$ fragment from pDE1 into YEp351 to yield pDE2. The $3.8 \mathrm{~kb} E c o \mathrm{RV}-$ Sal I fragment from pDE2 was then cloned into M13mp18 and the pDE2 $3.8 \mathrm{~kb}$ EcoRV-HindIII fragment was cloned into M13mp19 to produce $\mathrm{mpDE} 1$ and $\mathrm{mpDE} 2$, respectively. Deletions spanning the mpDE1 and mpDE2 inserts were generated using the method of Henikoff (1984). Overlapping deletions were sequenced with the Sequenase DNA Sequencing Kit from United States Biochemicals.

Iron uptake and reductase assays. Exponentially growing cells were chilled on ice for $20 \mathrm{~min}$, centrifuged at $1000 \mathrm{~g}$ for $5 \mathrm{~min}$ at $4{ }^{\circ} \mathrm{C}$, washed twice in ice-cold LIM-EDTA (i.e. LIM lacking EDTA), and resuspended in approximately $1 / 100$ th the original culture volume in LIM-EDTA. Cell suspensions were kept on ice prior to use. Uptake assay solutions were prepared by diluting ${ }^{59} \mathrm{FeCl}_{3}$ (Amersham) into chilled LIM - EDTA at the appropriate concentrations. In assays in which iron was supplied as $\mathrm{Fe}^{2+}, 1 \mathrm{~mm}$-sodium ascorbate was included in the assay solution. To begin the uptake assay, $50 \mu \mathrm{l}$ of cell suspension was added to $450 \mu$ l of assay solution and transferred to $30^{\circ} \mathrm{C}$. After $10 \mathrm{~min}$, the assay samples were chilled on ice, vacuum filtered through Whatman GF/C filters and washed in $10 \mathrm{ml}$ ice-cold SSW (1 mMEDTA, 20 mM-trisodium citrate $\mathrm{pH} 4 \cdot 2,1 \mathrm{~mm}-\mathrm{KH}_{2} \mathrm{PO}_{4}, 1 \mathrm{~mm}-\mathrm{CaCl}_{2}$, $5 \mathrm{~mm}-\mathrm{MgSO}_{4}, 1 \mathrm{~mm}-\mathrm{NaCl}$ ). Non-specific uptake due to surface adsorption was determined by preparing parallel assays that were held on ice for $10 \mathrm{~min}$ before filtration and washing. These background levels of cell-associated ${ }^{59} \mathrm{Fe}$ were subtracted out before uptake rates were calculated. ${ }^{59} \mathrm{Fe}$ levels were measured with a Packard Minaxi $\gamma$ Autogamma 5000 gamma counter. Specific activity, rate of decay and cell number were used to calculate the uptake rates.

Assays of the iron reductase were performed in a manner similar to that used for uptake assays. Aliquots $(50 \mu \mathrm{l})$ of the cell suspensions were inoculated into $950 \mu \mathrm{l}$ ice-cold LIM - EDTA supplemented with $10 \mu \mathrm{M}$ $\mathrm{FeCl}_{3}$ and $1 \mathrm{mM}$-bathophenanthroline disulphonate (BPS) (Landers \& $\mathrm{Zak}, 1958)$. Samples were incubated at $30^{\circ} \mathrm{C}$ for $10 \mathrm{~min}$ and then chilled on ice. Cells were removed by spinning for $20 \mathrm{~s}$ at $10000 \mathrm{~g}$, and the absorbance at $520 \mathrm{~nm}$ was measured. The concentration of iron reduced was determined by comparison to a standard curve. Background levels were determined using parallel samples that contained no cells; these values were then subtracted from the values obtained with the cell-containing samples before calculating the reduction rate.

\section{Results}

\section{LIM is iron-limiting}

Media capable of controlling cell growth by iron limitation can be difficult to prepare because iron is a major contaminant of reagents, glassware, etc., and is required by yeast in only trace amounts. One common approach to preparing an iron-limited medium is to extract the iron from the media (Nicholas, 1957; Hewitt, 1966). Small amounts of iron can then be added back to the medium to restore cell growth. A second method, which we used in this work, takes advantage of the fact
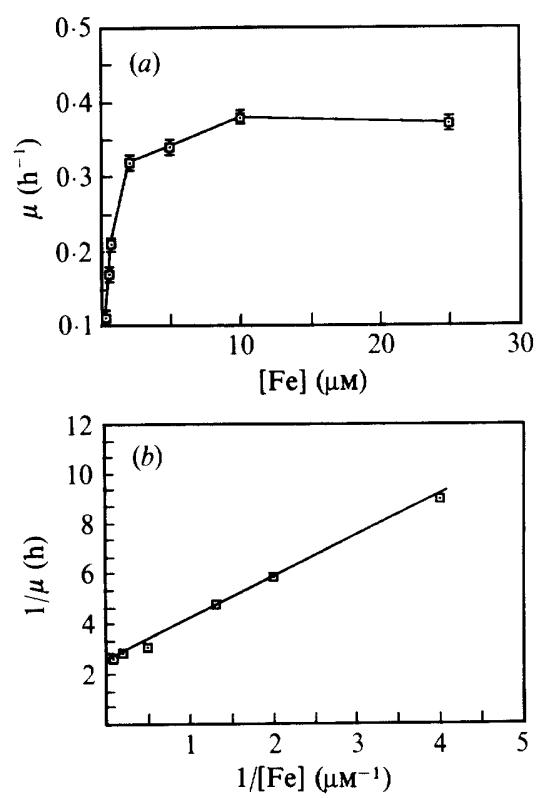

Fig. 1. Relationship between iron concentration and specific growth rate $(\mu)$. (a) Specific growth rates were determined for DBY2063 growing in LIM medium supplemented 0.25 to $25 \mu \mathrm{M}$ - Fe. Each point is the mean of three cultures; the error bars represent one standard deviation $\left(=0.01 \mathrm{~h}^{-1}\right)$. (b) The data shown in $(a)$ were plotted as $1 / \mu \mathrm{vs}$ $1 /[\mathrm{Fe}]$. The equation for this relationship was determined by linear regression $\left(r^{2}=0.993\right)$.

that chelating agents, such as EDTA, bind metal ions and make them unavailable to the cell. This approach was suggested by the work of F. M. M. Morel and coworkers (Morel et al., 1979; Anderson \& Morel, 1982) on iron limitation of phytoplankton. Iron limitation with chelators has several advantages over iron extraction methods. The resulting medium is less sensitive to contamination by iron, and precipitation of constituents is prevented.

A wild-type yeast strain, DBY2063, could not grow on LIM without added iron. Addition of $10 \mu \mathrm{M}-\mathrm{FeCl}_{3}$ was sufficient to promote cell growth, whereas $10 \mu \mathrm{M}$ supplements of $\mathrm{Zn}^{2+}, \mathrm{Cu}^{2+}, \mathrm{Mn}^{2+}, \mathrm{Mg}^{2+}$ and $\mathrm{Ca}^{2+}$ failed to stimulate growth. This observation precludes the possibility that the added $\mathrm{FeCl}_{3}$ was affecting the availability of another metal by titrating out the EDTA in the medium. To determine how different amounts of added iron affect cell growth, we measured the growth rate of DBY2063 on LIM supplemented with 0 to $25 \mu \mathrm{M}-\mathrm{FeCl}_{3}$ (Fig. 1a). The specific growth rate $(\mu)$ of DBY2063 increased as iron was added to the medium up to a concentration of $10 \mu \mathrm{M}$. The linearity of these data when displayed on a Lineweaver-Burk reciprocal plot (Fig. 1b) demonstrated that this response followed the relationship of Monod $\left(\mu=\mu_{\max } \times S /\left[K_{\mu}+S\right]\right)$, where $\mu=$ specific growth rate, $\mu_{\max }=$ maximum specific growth rate, $S=$ substrate concentration and $K_{\mu}=$ concentration 


\section{Table 2. Effect of EDTA on iron uptake and reduction}

Wild-type DBY2063 cells were grown to the exponential growth phase in $\operatorname{LIM}(10)$. These cells were collected and assayed for uptake of iron supplied as ${ }^{59} \mathrm{Fe}^{3+}$ or ${ }^{59} \mathrm{Fe}^{2+}$ and for reduction activity in LIM - EDTA and LIM. All assays were performed in $10 \mu \mathrm{M}-\mathrm{Fe}$. The mean values of two experiments, each performed in duplicate, is shown; the numbers in parentheses are the standard deviations.

\begin{tabular}{|c|c|c|c|}
\hline \multirow{2}{*}{$\begin{array}{l}\text { Assay } \\
\text { medium }\end{array}$} & \multicolumn{2}{|c|}{$\begin{array}{c}\text { Iron uptake rate } \\
\left.\text { [fmol } \min ^{-1}\left(10^{6} \text { cells }\right)^{-1}\right] \\
\text { with iron supplied as: }\end{array}$} & \multirow{2}{*}{ 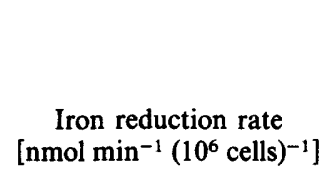 } \\
\hline & $\mathrm{Fe}^{3+}$ & $\mathrm{Fe}^{2+}$ & \\
\hline $\begin{array}{l}\text { - EDTA } \\
+ \text { EDTA }\end{array}$ & $\begin{array}{r}822( \pm 75) \\
32( \pm 15)\end{array}$ & $\begin{array}{r}894( \pm 33) \\
26( \pm 4)\end{array}$ & $\begin{array}{l}18( \pm 2) \\
19( \pm 1)\end{array}$ \\
\hline
\end{tabular}

of substrate that elicits the half-maximal growth rate (Monod, 1942). These data gave a value of $K_{\mu}$ for DBY 2063 of $0.8 \mu \mathrm{M}$ total Fe. The value of $\mu_{\max }$ in this medium was $0.39 \mathrm{~h}^{-1}$ and was attained when more than $10 \mu \mathrm{M}-\mathrm{Fe}$ was added.

\section{EDTA inhibits uptake but not reduction}

LIM prepared without EDTA supported cell growth without additional iron. It was clear from this result that the EDTA in the medium limits the availability of iron to the cells. EDTA may exert this effect by either preventing the reductase from reducing iron or by blocking uptake of $\mathrm{Fe}^{2+}$. To test these hypotheses, we determined how EDTA affects iron reduction and uptake when supplied to cells as either $\mathrm{Fe}^{3+}$ or $\mathrm{Fe}^{2+}$. DBY2063 cells were grown to the mid-exponential phase in LIM(10) and assayed in LIM or LIM prepared without EDTA (LIM-EDTA) for iron reductase activity and uptake of ${ }^{59} \mathrm{Fe}^{3+}$ or ${ }^{59} \mathrm{Fe}^{2+}$ (Table 2).

Uptake of iron, supplied as $\mathrm{Fe}^{3+}$, was inhibited by EDTA. This inhibition was not due to a block in reduction because this rate was not affected by the chelator. Because the vast majority of iron in reductase assays containing EDTA would be bound to the chelator $\left(K_{\mathrm{a}}=10^{25}\right)$, we conclude that the $\mathrm{Fe}^{3+}$-EDTA complex is an acceptable substrate for the reductase. Iron can be reduced in the uptake assay from $\mathrm{Fe}^{3+}$ to $\mathrm{Fe}^{2+}$ by adding $1 \mathrm{~mm}$-ascorbate. Uptake of $\mathrm{Fe}^{2+}$, as measured in the presence of ascorbate, was inhibited by EDTA as much as when iron was supplied as $\mathrm{Fe}^{3+}$. Therefore, the ironlimiting properties of EDTA are the result of its ability to chelate $\mathrm{Fe}^{2+}\left(K_{\mathrm{a}}=10^{14}\right)$ and make it unavailable for uptake.

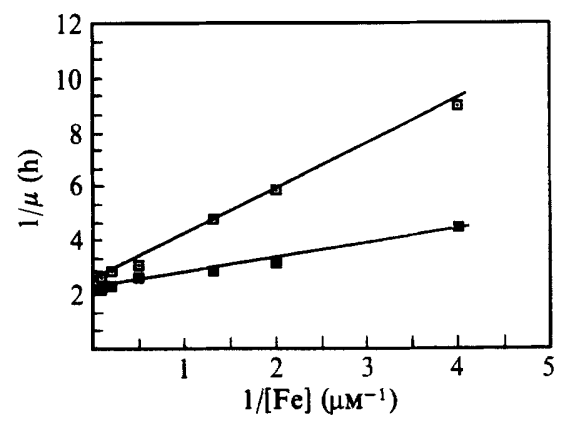

Fig. 2. Effects of pDE1 on cellular iron requirements. A LineweaverBurk reciprocal plot of the relationship between the concentration of iron supplemented into LIM medium and the specific growth rate, $\mu$,

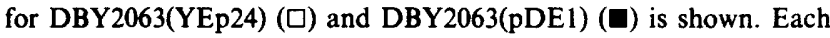
point is the mean of three cultures; the standard deviation of the specific growth rate was $0.01 \mathrm{~h}^{-1}$. The equations for these relationships were determined by linear regression $\left[r^{2}=0.997\right.$ for DBY2063(YEp24) and $r^{2}=0.991$ for DBY2063(pDE1)].

\section{Isolation of genes that enhance iron-limited growth}

Our ability to limit the iron available to cells allowed us to select for genes that lower the iron concentration in the medium required for efficient growth. We screened a yeast genomic library in a multicopy plasmid for genes that enhanced cell growth in LIM supplemented with $0.25 \mu \mathrm{M}-\mathrm{FeCl}_{3}$ [i.e. $\operatorname{LIM}(0 \cdot 25)$ ]. DBY2063 was transformed with a genomic plasmid library, pooled, and grown for several passages on $\operatorname{LIM}(0 \cdot 25)$ until librarytransformed cultures grew better than a vector-only control. Individual cells from these cultures were then cloned and tested for growth on $\operatorname{LIM}(0 \cdot 25)$. Two plasmids that enhance the growth rate of DBY2063 in iron-limited conditions were isolated from 15000 independent transformants. Restriction mapping showed that these plasmids contained overlapping but nonidentical inserts. The plasmid pDE1, which contained the smaller of the two inserts (approximately $6 \mathrm{~kb}$ ), was used in subsequent experiments.

\section{Effect of pDE1 on cell growth and iron uptake}

To ascertain the effect of $\mathrm{pDE} 1$ on the iron requirement of cells, we determined the relationship between the specific growth rate, $\mu$, and the concentration of iron in the medium ([Fe]). DBY2063 bearing pDE1 or the parental vector, YEp24, was grown in LIM containing a range of iron concentrations, and growth rates were measured (Fig. 2). The $K_{\mu}$ value of the pDE1-bearing strain, $0 \cdot 2 \mu \mathrm{M}-\mathrm{FeCl}_{3}$, was approximately one-fourth the $K_{\mu}$ of the parent strain $(0.8 \mu \mathrm{M}$, Fig. 1) and the YEp24 control $(0.7 \mu \mathrm{M}, \mathrm{Fig}$. 2). No difference in growth rate was observed for these strains when iron was not limiting. 


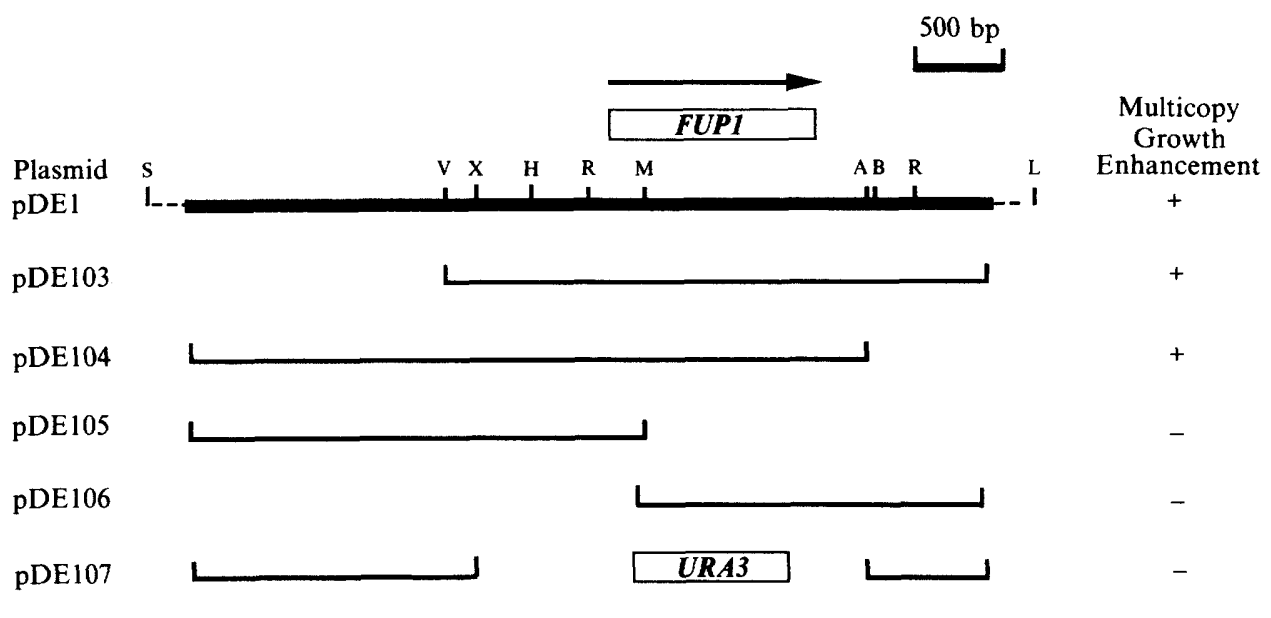

Sequenced region

Fig. 3. Restriction maps of the yeast genomic fragments in pDE1 and its derivatives. The plasmid pDE1 was digested with the restriction enzymes $\operatorname{SnaBI}(\mathrm{A}), \operatorname{BamHI}(\mathrm{B}), E c o R I(\mathrm{R}), E c o R V(\mathrm{~V}), \operatorname{MluI}(\mathrm{M}), \operatorname{SmaI}(\mathrm{S}), \operatorname{SalI}(\mathrm{L}), X h o \mathrm{I}(\mathrm{H})$ and $X b a \mathrm{I}(\mathrm{X})$, and the products were analysed by agarose gel electrophoresis. The map shows the positions of restriction sites within the pDE1 insert (thick line) and flanking vector (dashed line) DNA. The open box labelled FUPI indicates the location of the open reading frame as determined by DNA sequencing and the arrow indicates the direction of transcription. The lines below the map represent the fragments that are present in the subclones pDE103, pDE104, pDE105, pDE106 and pDE107. The URA3 gene was inserted into the deletion interval in pDE107. The five resulting plasmids were transformed into DBY2063 and assayed for their ability to enhance cell growth in iron-limited medium by determining the growth of the transformant in LIM(0.25). To the right of each line is the result of these growth tests. The region sequenced is also indicated.

\section{Table 3. Effect of multiple FUP1 copies on iron uptake}

DBY2063, DBY2063(YEp24) and DBY2063(pDE1) were grown exponentially in $\operatorname{LIM}(0 \cdot 25)$ and assayed for uptake in $2 \mu \mathrm{M}$-iron supplied as ${ }^{59} \mathrm{Fe}^{3+}$. The mean values of two experiments, each performed in duplicate, are shown; the numbers in parentheses are the standard deviations.

\begin{tabular}{lc}
\hline \hline Plasmid & $\begin{array}{c}\text { Iron uptake rate } \\
{\left[\mathrm{fmol} \mathrm{min}^{-1}\left(10^{6} \text { cells }\right)^{-1}\right]}\end{array}$ \\
\hline None & $97( \pm 6)$ \\
YEp24 & $78( \pm 2)$ \\
pDE1 & $506( \pm 2)$ \\
\hline \hline
\end{tabular}

Thus, the insert in pDE1 enhanced the ability of cells to grow under iron-limiting conditions.

One possible mechanism by which the plasmid enhanced cell growth was by stimulating the iron uptake apparatus. To test this hypothesis, we grew DBY2063 and DBY2063 transformed with either YEp24 or pDE1 in $\operatorname{LIM}(0.25)$ and assayed them for uptake of iron supplied as $\mathrm{Fe}^{3+}$ (Table 3). Uptake activity was five- to sixfold higher in the pDE1 transformant than in untransformed cells or those transformed with the vector only.

\section{Analysis of the FUP1 gene}

To determine the location of the gene responsible for this effect within the $6 \mathrm{~kb}$ insert of pDE1, deletions were generated in this plasmid and tested for their ability to enhance growth of DBY2063 on $\operatorname{LIM}(0 \cdot 25)$ (Fig. 3). The results indicated that the gene is located between the $S n a \mathrm{BI}$ and $E c o \mathrm{RV}$ sites of the pDE1 insert. The sequence of this region was determined and a single large open reading frame (ORF) of 1146 bases was found. This ORF was found to be identical to the MSN1 gene [see Estruch and Carlson (1990) for the sequence]. We refer to this gene as FUP1 for 'ferric utilization proficient'. The FUPI ORF was affected by all deletions that disrupted the growth effect of the plasmids. The gene encodes a protein of 382 amino acids with a predicted molecular mass of $43 \mathrm{kDa}$. A search of the NBRF protein database found no proteins similar to the FUP1 protein (Lipman \& Pearson, 1985). The codon adaptation index, a measure of codon bias, of FUPI was calculated to be $0 \cdot 104$, suggesting that the gene is not highly expressed (Sharp \& $\mathrm{Li}, 1987$ ). The protein is rich in serine and threonine $(17 \%)$ and asparagine plus glutamine $(18 \%)$. A hydropathy plot of the FUP1 amino acid sequence generated by the method of Kyte \& Doolittle (1982) shows a largely hydrophilic profile. The longest region of hydrophobicity (residues 85 to 105) has an average 


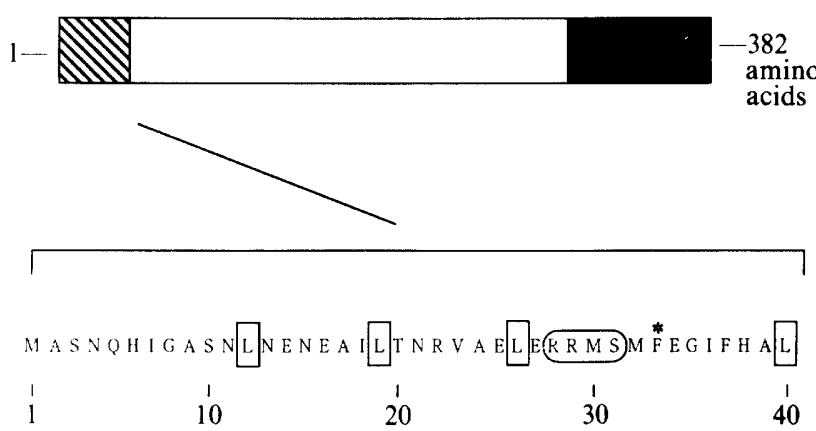

Fig. 4. Schematic representation of the FUP1 protein. The 382 amino acid FUP1 protein is represented by the box. The shaded portion represents the basic $\mathrm{C}$-terminus and the hatched portion represents the domain containing the putative leucine zipper, amino acids 1 to 40 . The amino acid sequence from residue 1 to 40 is also shown. The repeated leucine residues are boxed; the phenylalanine that is present at the gap in the heptad repeat is marked by the asterisk. The consensus target sequence, RRXS, for cAPK protein phosphorylation is circled.

hydropathy index of $+0 \cdot 4$. We have noted some specific features of the FUP1 amino acid sequence (Fig. 4). The C-terminus is basic, having a net charge of +13 over 78 residues. There is a potential leucine zipper, a series of four heptad leucine repeats, spanning residues 12 to 40 , with one gap at position 33 (Landschulz et al., 1988). We have also noted a consensus target sequence for phosphorylation of the protein by the cAMP-dependent protein kinase, RRXS, at amino acids 28 to 31 (Kemp et al., 1977).

\section{Effect of a FUP1 deletion allele on cell growth and iron uptake}

A deletion/substitution mutation in which the entire FUPI gene had been removed was constructed by deleting the SnaBI-XhoI interval and inserting the $U R A 3$ gene (pDE107, Fig. 3). When this allele, designated fup $1-1:: U R A 3$, was tested on a yeast multicopy plasmid vector, it did not enhance cell growth in $\operatorname{LIM}(0 \cdot 25)$. A fragment containing the fup $1-1:: U R A 3$ allele was introduced into DBY2063, and we selected for $\mathrm{URA}^{+}$prototrophs. A URA ${ }^{+}$transformant, DEY1194, was analysed by Southern blotting and determined to contain the disruption allele at the FUPI locus (data not shown).

No defect in growth was observed when DEY1194 was cultured on $\operatorname{LIM}(0 \cdot 75)$, a medium in which cells are ironlimited. Thus, a strain completely lacking the FUPI product was wild-type for growth in iron-limiting conditions. Furthermore, no growth defect was observed when this strain was tested for growth on rich media containing either glucose or lactate as the carbon source
Table 4. Effect of FUP1 disruption on iron uptake

DEY1296 (wild-type) and DEY1298 ( fup 1-1::URA3) were grown to exponential phase in SD-glucose or SD-raffinose. These cells were assayed for iron uptake with $2 \mu \mathrm{M}$-iron supplied as ${ }^{59} \mathrm{Fe}^{3+}$ or ${ }^{59} \mathrm{Fe}^{2+}$. The numbers in parentheses are the standard deviations of two experiments, each performed in duplicate.

\begin{tabular}{|c|c|c|c|c|}
\hline \multirow[b]{3}{*}{ Genotype } & \multicolumn{4}{|c|}{$\begin{array}{l}\text { Iron uptake rate }\left[\mathrm{fmol} \mathrm{m^{-1 }}\left(10^{6} \text { cells }\right)^{-1}\right] \\
\text { for cells grown in: }\end{array}$} \\
\hline & \multicolumn{2}{|c|}{ Glucose } & \multicolumn{2}{|c|}{ Raffinose } \\
\hline & $\mathrm{Fe}^{3+}$ & $\mathrm{Fe}^{2+}$ & $\mathrm{Fe}^{3+}$ & $\mathrm{Fe}^{2+}$ \\
\hline Wild-type & $12 \cdot 3( \pm 3)$ & $113.9( \pm 18)$ & $16 \cdot 5( \pm 4)$ & $157.5( \pm 9)$ \\
\hline fup 1-1::URA3 & $15 \cdot 4( \pm 2)$ & $130 \cdot 3( \pm 13)$ & $8 \cdot 6( \pm 2)$ & $93.0( \pm 5)$ \\
\hline
\end{tabular}

at either 30 or $37^{\circ} \mathrm{C}$. However, we did note that DEY 1194 grew at approximately $75 \%$ of the wild-type rate in media containing raffinose as the carbon source.

We tested if the growth defect on raffinose was associated with a defect in iron uptake. Wild-type and fup 1-1::URA3 cells were grown on glucose and raffinose and assayed for their iron uptake rate when iron was supplied as $\mathrm{Fe}^{3+}$ or $\mathrm{Fe}^{2+}$ (Table 4). The uptake rates of glucose- and raffinose-grown wild-type and fup $1-1:: U R A 3$ cells were very low when assayed with $\mathrm{Fe}^{3+}$, but elevated approximately 10 -fold when assayed with $\mathrm{Fe}^{2+}$. This result was consistent with our observation that the iron reductase was almost undetectable in these cells (data not shown). Therefore, the iron reductase is rate-limiting for uptake in cells grown in these media. Glucose-grown wild-type and mutant cells showed no difference in uptake rate. However, in raffinose-grown cells, the uptake rate observed for the fup $1-1:: U R A 3$ strain was reduced to 50 to $60 \%$ of wildtype rates.

\section{Discussion}

We have used a genetic strategy to isolate genes that affect iron-limited growth. Our prediction was that if the product of a gene was itself limiting in low iron, overproduction of that protein would enhance cell growth. The higher gene dosage present in a strain containing a multicopy plasmid often results in the accumulation of higher levels of the product of a plasmid-borne gene relative to the level produced by the chromosomal locus alone (Rine, 1991). Vectors of the type used in this study are present in 25 to 100 copies per cell (Clark-Walker \& Miklos, 1974).

The FUP1 gene was isolated because of its ability to enhance iron-limited growth. We demonstrated that the FUP1 gene, when present in multiple copies, lowers the 
$K_{\mu}$ for growth of a wild-type strain by fourfold without affecting the growth rate when iron was in excess. Our prediction is that this effect is due to overproduction of the FUPI gene product. We have demonstrated that higher levels of FUPI mRNA accumulate in pDE1bearing cells than in wild-type cells (data not shown).

It seems likely that FUPI is involved in the uptake of iron. We observed that strains bearing multiple copies have elevated levels of iron uptake. Yet a fupl deletion mutant grows normally in iron-limiting media and exhibits wild-type iron uptake rates when grown on glucose and approximately $50 \%$ of wild-type when grown on raffinose. One explanation for this apparent paradox is that the function of the FUP1 gene product is supplied by more than one gene. We have isolated a second gene, $F U P 2$, by the same selection scheme used here to isolate FUP1. FUP1 and FUP2 may encode functionally redundant proteins.

What role might FUPl play in iron assimilation? The hydrophilic composition of the FUP1 amino acid sequence suggests that the product is an intracellular protein and not membrane localized. FUP1 may activate the transcription of genes whose products are involved in iron uptake. The basic C-terminus may act as a DNA binding domain. The presence of a putative leucine zipper, which acts as a dimerization domain in many proteins, suggests that the FUP1 protein functions as a homo- or heterodimer. A potential phosphorylation target site within this domain suggests that the cAMPdependent protein kinase (cAPK) may regulate FUP1 activity by affecting dimerization. Protein phosporylation by cAPK is a major mechanism of carbon source regulation in yeast, altering the activity of several enzymes (Rittenhouse et al., 1987; Thevelein, 1988) and at least one transcriptional activator, $A D R I$ (Cherry et al., 1989). Because growth on glucose initiates a cascade of cAPK-mediated phosphorylation (Matsumoto et al., 1982; Cannon \& Tatchell, 1987; Toda et al., 1987), the FUP1 protein may be phosphorylated in glucose-grown cells.

Estruch \& Carlson (1990) concurrently isolated FUP1, which they have called $M S N I$, as a multicopy suppressor of temperature sensitive mutations in the $S N F 1$ locus. $S N F I$ encodes a protein kinase that is required for transcription of glucose-repressible genes when cells are grown on sugars other than glucose, such as raffinose, sucrose and galactose, or on non-fermentable carbon sources, such as lactate or ethanol. When present on a multicopy plasmid, the FUP1/MSN1 gene restores growth and regulated expression of at least one glucoserepressible gene, SUC2. A fup $1 / m s n 1$ disruption, however, caused only a 3- to 4-fold reduction in derepressed levels of invertase, the product of the $S U C 2$ locus, when cells were grown on raffinose.
Estruch \& Carlson (1990) presented several lines of evidence to prove that $F U P I / M S N I$ is a transcriptional activator. A FUP1/MSN1 $\beta$-galactosidase fusion protein was nuclear localized, and can bind DNA. Furthermore, a lexA-FUP1/MSN1 fusion protein could promote transcription from a reporter gene containing a lexA operator as an upstream activation sequence. These results, along with the effects of overexpression on $S U C 2$ expression, suggested that the FUPI/MSNI gene encodes a transcriptional activator that plays a role in gene regulation in response to carbon source.

There is a remarkable similarity between the effects of altered FUPI/MSNI copy number on SUC2 expression and iron uptake activity. What is the connection between glucose repression and iron metabolism? In a fupl/msn I mutant, we have observed a defect in iron uptake with raffinose-grown cells but not with glucose-grown cells. Lesuisse et al. (1987) have shown that iron uptake is induced by growth on non-fermentable carbon sources. This induction is presumably because iron in the form of haem is required to metabolize these nutrients. These observations suggest that, to some extent, carbon source utilization and iron uptake are coregulated processes. FUP1/MSN1 may play a role in this regulation by activating transcription of genes involved in both of these responses.

We would like to thank J. Ryan and R. Hudson for assistance with the development of LIM medium and atomic absorption spectroscopy. We are grateful to Francisco Estruch and Marion Carlson for discussing their data with us prior to publication. Also, we thank Sandra Davis-Kaplan for expert technical assistance, Jerry Kaplan for invaluable discussion and advice, and Ann Thering, David Stillman, David Sipe and Betty Leibold for critical reading of the manuscript. We thank Mark Goebl for bringing to our attention the identity of FUPI and $M S N 1$. The FUP1/MSN1 sequence has been transmitted to the EMBL Data Library by F. Estruch and M. Carlson under accession number X54324. This work was supported by National Institutes of Health grant GM37129-04 (L. G.) and DK30534 to Dr Jerry Kaplan. D.E. was supported by a Jane Coffin Childs Memorial Fund for Medical Research postdoctoral fellowship and NIH postdoctoral training grant 5T3 HL07636-02.

\section{References}

ANDERSON, M. A. \& Morel, F. M. M. (1982). The influence of aqueous iron chemistry on the uptake of iron by the coastal diatom Thalassiosira weissflogii. Limnological Oceanography 27, 789-801.

CANNON, J. F. \& TATCHELl, K. (1987). Characterization of Saccharomyces cerevisiae genes encoding subunits of cyclic AMP-dependent protein kinase. Molecular and Cellular Biology 7, 2653-2663.

CARLSON, M. \& BotsTein, D. (1982). Two differentially regulated mRNAs with different $5^{\prime}$ ends encode secreted and intracellular forms of yeast invertase. Cell 28, 145-154.

Cherry, J. R., Johnson, T. R., Dollard, C., Shuster, J. R. \& Denis, C. L. (1989). Cyclic AMP-dependent protein kinase phosphorylates and inactivates the yeast transcriptional activator ADR1. Cell 56, 409-419. 
Clark-Walker, G. D. \& Miklos, G. L. G. (1974). Localization and quantitation of circular DNA in yeast. European Journal of Biochemistry 41, 359-365.

Dancis, A., Klausner, R. D., Hinnebusch, A. G. \& Barriocanal, J. G. (1990). Genetic evidence that ferric reductase is required for iron uptake in Saccharomyces cerevisiae. Molecular and Cellular Biology 10, 2294-2301.

Estruch, F. \& CaRLSON, M. (1990). Increased dosage of the MSNI gene restores invertase expression in yeast mutants defective in the SNF1 protein kinase. Nucleic Acids Research 18, 6959-6964.

Greene, J. R. \& Guarente, L. (1987). Subcloning. Methods in Enzymology 152, 512-522.

HeNIKofF, S. (1984). Unidirectional digestion with exonuclease III creates targeted breakpoints for DNA sequencing. Gene 28, 351359.

HEwITT, E. J. (1966). Sand and water culture methods used in the study of plant nutrition. Farnham Royal, Bucks: Commonwealth Agricultural Bureaux.

Hill, J. E., Myers, A. M., Koerner, T. J. \& Tzalgoloff, A. (1986). Yeast $/ E$. coli shuttle vectors with multiple unique restriction sites. Yeast 2, 163-167.

Kemp, B. E., Graves, D. J., Benjamini, E. \& Krebs, E. G. (1977). Role of multiple basic residues in determining the substrate specificity of cyclic AMP-dependent protein kinase. Journal of Biological Chemistry 252, 4888-4894.

KYTE, J. \& DoolitTle, R. F. (1982). A simple method for displaying the hydropathic character of a protein. Journal of Molecular Biology 157, 105-132.

LANDERS, J. W. \& ZAK, B. (1958). Determination of serum copper and iron in a single small sample. American Journal of Clinical Pathology 29, 590-592.

Landschulz, W. H., Johnson, P. F. \& MCKNight, S. L. (1988). The leucine zipper: a hypothetical structure common to a new class of DNA binding proteins. Science 240, 1759-1764.

Lesuisse, E. \& LABBE, P. (1989). Reductive and nonreductive mechanisms of iron assimilation by the yeast Saccharomyces cerevisiae. Journal of General Microbiology 135, 257-263.

Lesuisse, E., RAGUZZI, F. \& Crichton, R. R. (1987). Iron uptake by the yeast Saccharomyces cerevisiae: involvement of a reduction step. Journal of General Microbiology 133, 3229-3236.

Lipman, D. J. \& PeArson, W. R. (1985). Rapid and sensitive protein similarity searches. Science 227, 1435-1441.

Matsumoto, K., UNo, I., Oshima, Y. \& Ishikawa, T. (1982). Isolation and characterization of yeast mutants deficient in adenylate cyclase and cAMP-dependent protein kinase. Proceedings of the National Academy of Sciences of the United States of America 79, 2355-2359. MONOD, J. (1942). Recherches sur le croissance des cultures bacteriennes. Paris: Herman.

Morel, F. M. M., Rueter, J. G., Anderson, D. M. \& Guillard, R. R. L. (1979). Aquil: a chemically defined phytoplankton culture medium for trace metal studies. Journal of Phycology 15, 135-151.

Nicholas, D. J. D. (1957). Microbiologial methods for determining magnesium, iron, copper, zinc, manganese, and molybdenum. Methods in Enzymology 3, 1035-1041.

RiNE, J. (1991). Gene overexpression in studies of Saccharomyces cerevisiae. Methods in Enzymology 194, 239-251.

Rittenhouse, J., MoberLy, L. \& Marcus, F. (1987). Phosphorylation in vivo of yeast (Saccharomyces cerevisiae) fructose-1,6-bisphosphatase at the cyclic AMP-dependent site. Journal of Biological Chemistry 262, 10114-10119.

RothsteIN, R. (1991). Targeting, disruption, replacement, and allele rescue: integrative DNA transformation in yeast. Methods in Enzymology 194, 281-301.

SambrooK, J., Fritsch, E. F. \& Maniatis, T. (1989). Molecular Cloning: A Laboratory Manual, 2nd edn. Cold Spring Harbor, NY: Cold Spring Harbor Laboratory.

SCHWYN, B. \& NeILANDS, J. B. (1987). Universal chemical assay for the detection and determination of siderophores. Analytical Biochemistry $160,47-56$.

SharP, P. M. \& LI, W.-H. (1987). The codon adaptation index - a measure of directional synonymous codon usage bias, and its potential applications. Nucleic Acids Research 15, 1281-1295.

Sherman, F., Fink, G. R. \& Hicks, J. B. (1986). Methods in Yeast Genetics. Cold Spring Habor, NY: Cold Spring Harbor Laboratory.

TheVelein, J. M. (1988). Regulation of trehelase activity by phosphorylation-dephosphorylation during developmental transitions in fungi. Experimental Mycology 12, 1-12.

Toda, T., Cameron, S., Sass, P., Zoller, M., ScotT, J. D., MCMullen, B., HuRwitz, M., KREBS, E. G. \& Wigler, M. (1987). Cloning and characterization of $B C Y I$, a locus encoding a regulatory subunit of the cyclic AMP-dependent protein kinase in Saccharomyces cerevisiae. Molecular and Cellular Biology 7, 1371-1377.

WICKERHAM, L. J. (1946). A critical evaluation of the nitrogen assimilation tests commonly used in the classification of yeasts. Journal of Bacteriology 52, 293-301.

Winkelmann, G., van der Helm, D. \& Neilands, J. B. (editors) (1987). Iron transport in microbes, plants and animals. New York: $\mathrm{VCH}$ Verlagsgesellschaft. 